\title{
High (ultrahigh) pressure metamorphic terrane rocks as the source of the detrital garnets from the Middle Jurassic sands and sandstones of the Cracow Region (Cracow-Wieluń Upland, Poland)
}

\author{
ŠTEFAN MÉRES ${ }^{1}$, ROMAN AUBRECHT $^{2,4}$, MICHAŁ GRADZIŃSKI ${ }^{3}$ AND MILAN SÝKORA ${ }^{2}$ \\ ${ }^{1}$ Department of Geochemistry, Faculty of Natural Sciences, Comenius University, Mlynská dolina - G, 84215 \\ Bratislava, Slovakia.E-mail: meres@fns.uniba.sk \\ ${ }^{2}$ Department of Geology and Paleontology, Faculty of Natural Sciences, Comenius University, Mlynská dolina - G, \\ 84215 Bratislava, Slovakia. E-mail: aubrecht@fns.uniba.sk; sykora@fns.uniba.sk \\ ${ }^{3}$ Institute of Geological Sciences, Jagiellonian University, Oleandry 2a, PL-30-063 Cracow, Poland. \\ E-mail: gradzinm@ing.uj.edu.pl \\ ${ }^{4}$ Geophysical Institute, Slovak Academy of Sciences, Dúbravská cesta 9, SK-845 28 Bratislava, Slovakia.
}

\begin{abstract}
:
Aubrecht, R., Méres, Š., Gradziński, M. and Sýkora, M. 2012. High (ultrahigh) pressure metamorphic terrane rocks as the source of the detrital garnets from the Middle Jurassic sands and sandstones of the Cracow Region (CracowWieluń Upland, Poland). Acta Geologica Polonica, 62 (2), 231-245. Warszawa.

The Middle Jurassic (Upper Bathonian/Lower Callovian) sands and sandstones of the Cracow-Wielun Upland contain detrital garnets with high contents of the pyrope molecule (30-73 mol \%). The predominance of detrital pyrope garnets, and inclusions represented mainly by omphacite and kyanite, show that the garnets were derived from high (ultrahigh) pressure (H/UHP) metamorphic terrane rocks (garnet peridotites, eclogites and granulites). Their source is unknown. The Moldanubian Zone of the Bohemian Massif is closely comparable. However, the terranes between this zone and the Cracow-Wieluń Upland are dominated by almandine garnets. The relatively low proportion of almandine garnets in the examined samples indicates that transport of the detrital material could not have been from a far distant source as the garnet assemblage would otherwise be strongly dominated by almandine. A less distant possible source could have been the Góry Sowie Mts., which incorporate UHP/HP metamorphic rocks, but the exposed areal extent of these rocks is too small. It is possible that larger portions of these metamorphic rocks are buried beneath the Cenozoic cover and might have earlier represented a larger source area. Reworking of the entire heavy mineral spectra from older clastics is improbable because of the low maturity of the heavy mineral assemblages (higher proportion of less stable minerals). The source area therefore remains unknown. Most probably it was formed by primary crystalline complexes of lower crust to mantle origin, outcrops of which were not far distant from the area of deposition. Similar detrital garnet compositions were also recorded in the Outer Western Carpathians (Flysch Zone, Pieniny Klippen Belt), i.e. the crustal segments which formed the Silesian and Magura cordilleras; the Czorsztyn Swell was also formed by similar rocks.
\end{abstract}

Key words: Detrital garnets; Provenance analysis; Jurassic; Polish platform.

\section{INTRODUCTION}

Heavy mineral study is a tool of palaeogeographic research that complements facies and palaeobiogeo- graphic data. Middle Jurassic sands and sandstones in the southern part of the Cracow-Wielun Upland were analysed for heavy minerals to compare the assemblages with those published from the Tethyan Jurassic of the 
Western Carpathians (Loziński 1956, 1957, 1966; Aubrecht 1993, 2001), Eastern Alps (Faupl 1975) and from the Tethyan margin of the Bohemian Massif (Štelcl et al. 1972, 1977). The crucial problem to be solved by the previous research was the provenance of the individual crustal blocks of the Tethyan units before the Jurassic rifting.

The results from the Western Carpathian Jurassic summarized from the above-mentioned literature show big differences in the heavy mineral spectra between the internides and the externides. The externides are dominated by garnet, accompanied by zircon, rutile and tourmaline, with subordinate amounts of other minerals. The internides are characterized by a predominance of tourmaline and apatite, accompanied by zircon and rutile. The results from the margin of the Bohemian Massif correlate well with the results from the externides.

\section{GEOLOGICAL SETTING}

Transgressive Middle Jurassic sediments of the Cracow region (Cracow-Wielun Upland, Poland) rest on the erosion surface formed on older Palaeozoic and Mesozoic rocks. In some places older Middle Jurassic continental clays (mainly lacustrine) are preserved (Kopik 1997). The Middle Jurassic commences with basal arenites (quartz sands and sandstones; Text-fig. 2), including some conglomeratic horizons. The basal arenites do not contain any fossils and are most probably of fluvial origin (Dżułyński 1950). The uneven basement topography is reflected by variable thicknesses of the arenites, from 0 to around $10 \mathrm{~m}$ (Hoffmann and Gradziński 2004). The arenites grade up into sands, sandstones and sandy limestones with marine faunas. The overlying marine clastics represent the Lower Callovian (Giżejewska and Wieczorek 1976; Ogg et al. 1991; Dembicz et al. 2006). Thus, the underlying basal arenites are most probably of Bathonian or earliest Callovian age.

Results of heavy mineral analysis of Middle Jurassic sediments of the Cracow region were published by Przybyłowicz (1958) and Krysowska (1960, 1962). Przybyłowicz (1958) reported heavy mineral spectra with variable amounts of garnet, tourmaline, rutile and zircon, with subordinate amounts of other minerals; Krysowska $(1960,1962)$ mentioned similar heavy mineral spectra but mostly dominated by garnet. This paper focuses on the provenance of the detrital garnets in these assemblages. The following localities were studied (Text-fig. 1): quarry near Czatkowice beside the road to Dębnik (N 50¹3'16.5”, E 1947'41.3”),

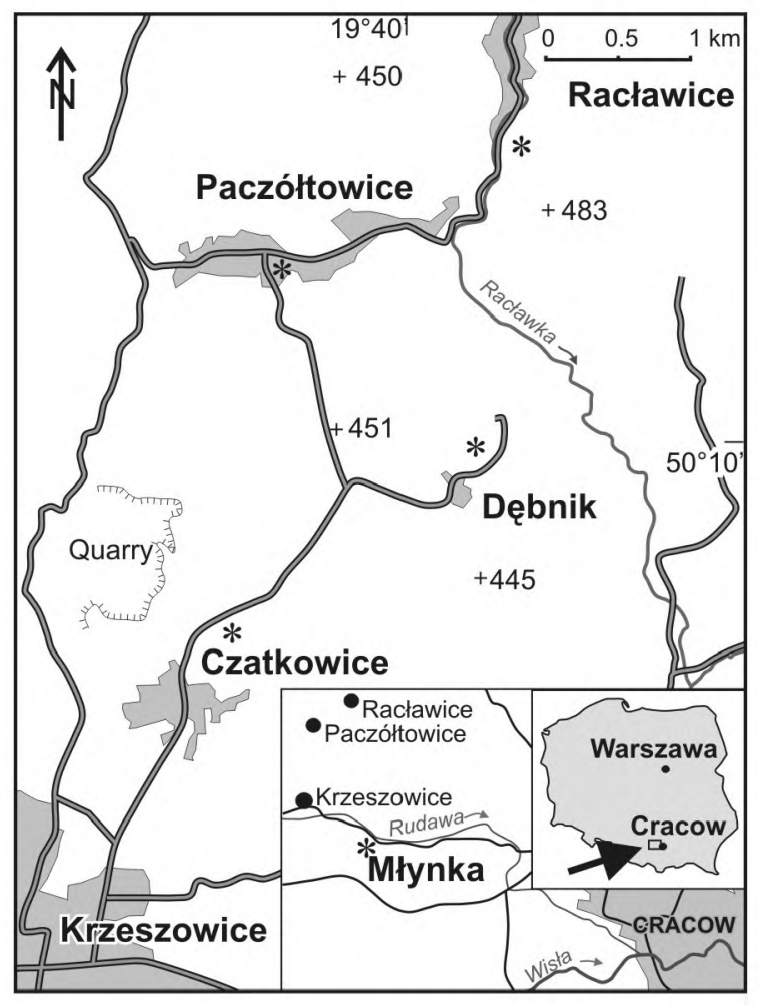

Text-fig. 1. Positions of the sampled sites (indicated by asterisks)

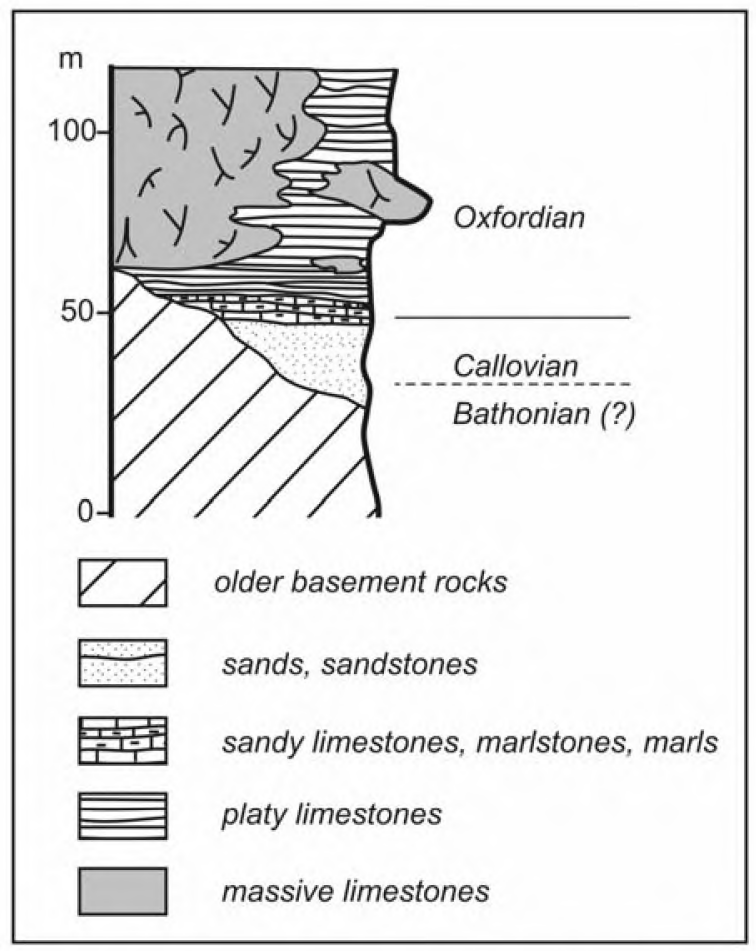

Text-fig. 2. Jurassic deposits of the Cracow Region. General geological section; after Matyszkiewicz and Krajewski (2007) 


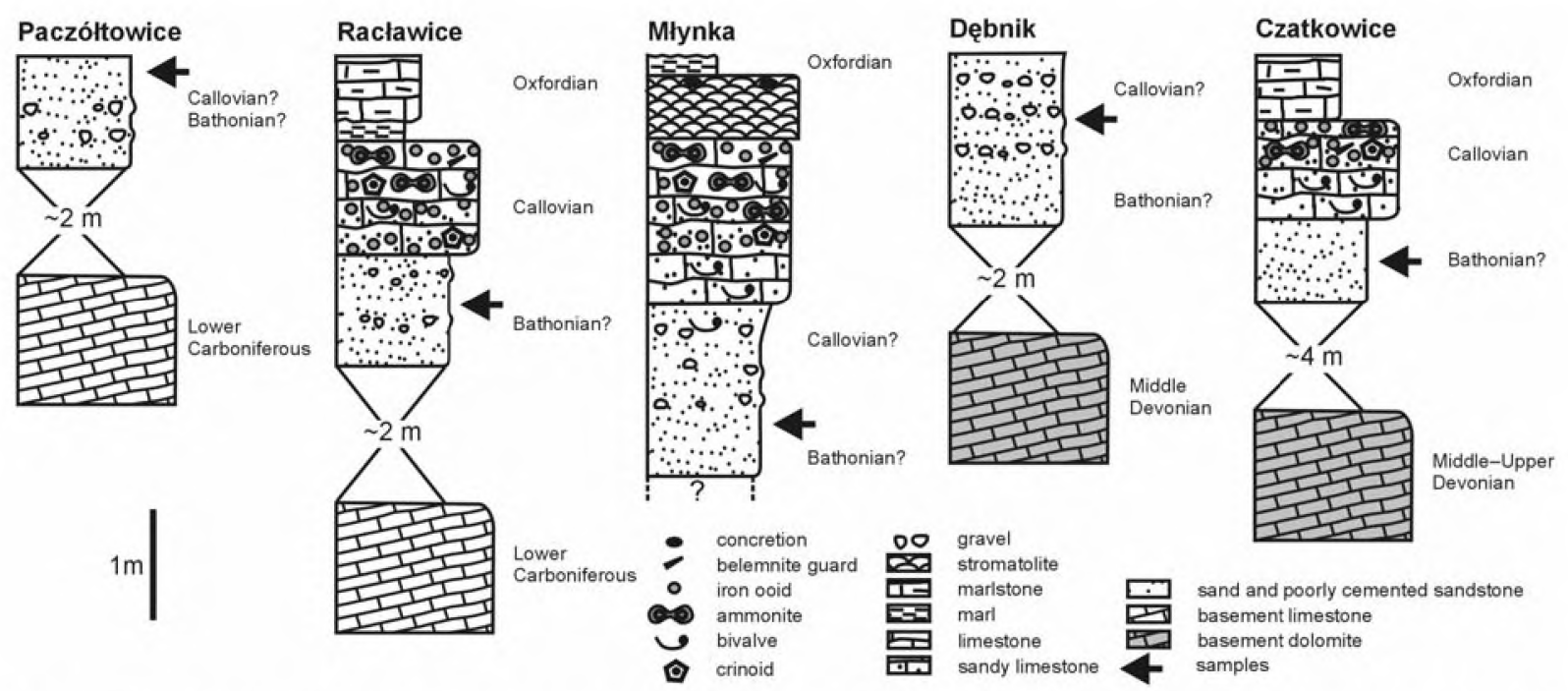

Text-fig. 3. Studied sections - Młynka simplified and modified after Dembicz et al. (2006); Czatkowice based on Mariusz Hoffmann unpublished data; Racławice based on Andrzej Górny unpublished data

Dębnik Quarry (N 5009'52.1", E 1940'17.4"), Paczóltowice (N 50¹0'33", E 19³9'22.9'), Młynka (N $50^{\circ} 06^{\prime} 33.5^{\prime \prime}$, E $\left.19^{\circ} 41^{\prime} 16.4^{\prime \prime}\right)$ and Racławice (N $\left.50^{\circ} 11^{\prime} 7.8^{\prime \prime}, \mathrm{E} 19^{\circ} 40^{\prime} 34.5^{\prime \prime}\right)$. In the Czatkowice and Dębnik localities the arenites overlie Devonian carbonates whereas in Paczóltowice and Racławice they overlie Lower Carboniferous (Mississippian) limestones (Text-fig. 3). The basement to the Middle Jurassic deposits in Młynka is not known but it probably consists of Carboniferous rocks. The samples were taken from structureless yellowish sands to poorly lithified sandstones, free of any faunal relics (most probably the fluvial part of the formation).

\section{MATERIALS AND METHODS}

From each locality, one $2-3 \mathrm{~kg}$ sand (to sandstone) sample was taken. The sandstones are soft and only some crushing by hammer was needed. The heavy minerals were separated in heavy liquids (bromoform, density ca 2.8). The $0.08-0.25 \mathrm{~mm}$ fraction was studied by transmitted light; the whole fraction was also examined under a binocular microscope. Percentage ratios of the heavy mineral assemblages were determined by ribbon point counting. The opaque minerals in all samples were dominated by diagenetic Fe-minerals - limonite and pyrite, which are insignificant from the point of view of clastic provenance. Therefore, the results presented in this paper are based only on the translucent heavy minerals.

The chemical compositions of the garnets and their inclusions (Tables 2, 3) were determined using a CAMECA SX-100 electron microprobe at the State Geo- logical Institute of Dionýz Štúr in Bratislava, Slovakia. The analytical conditions were as follows: $15 \mathrm{kV}$ accelerating voltage and $20 \mathrm{nA}$ beam current, with a peak counting time of 20 seconds and a beam diameter of $2-10 \mu \mathrm{m}$. Raw counts were corrected using a PAP routine.

\section{RESULTS}

\section{Percentage ratios of the heavy minerals}

The heavy mineral spectra are slightly dominated by garnet but the contents of zircon, rutile and tourmaline are also high, which slightly contradict the previous results of Krysowska $(1960,1962)$ but are in accordance with those of Przybylowicz (1958). These four minerals were accompanied by lesser amounts of staurolite, apatite, kyanite, titanite, hornblende and epidote (Table 1, Text-figs 4, 5). The heavy mineral spectra show variable ZTR indexes (Table 1), from 39\% in the Młynka sample to $86 \%$ in the Dębnik sample. This index represents the percentage of the ultrastable trinity zircon-tourmaline-rutile in the heavy mineral spectrum (Hubert 1962). It reflects the overall maturity of the sediment and also indicates a possible redeposition from older sediments. The higher the index, the more mature is the sedimentary material. The index increases with longer transport and abrasion of the detrital grains, but intrastratal dissolution also plays a significant role. Intrastratal dissolution is influenced by burial depth (Morton 1987) as well as by organic acids present in the sediment (Hansley 1987). 


\begin{tabular}{|l|c|c|c|c|c|c|c|c|c|c|c|}
\hline locality & \multicolumn{10}{|c|}{ minerals \% } & ZTR index \\
\hline & Grt & Zrn & Rt & Tur & Ap & Hbl & Ttn & St & Ky & Ep & \\
\hline Czatkowice & 21 & 35 & 12 & 24 & 1 & 0 & 0 & 4 & + & 2 & 71 \\
Paczółtowice & 36 & 13 & 18 & 23 & 1 & 0 & 0 & 5 & + & 3 & 54 \\
Racławice & 28 & 20 & 36 & 7 & 5 & 0 & 0 & 1 & 0 & 3 & 63 \\
Débnik & 3 & 19 & 26 & 41 & 1 & 1 & 0 & 6 & 0 & 3 & 86 \\
Młynka & 56 & 20 & 14 & 5 & 1 & 0 & 2 & 2 & + & 0 & 39 \\
\hline
\end{tabular}

Explanations: Grt - garnet, Zrn - zircon, Rt - rutile, Tur - tourmaline, Ap - apatite, Hbl - hornblende, Ttn - titanite, St - staurolite, Ky - kyanite, Ep - epidote. All symbols for rock-forming minerals in this paper were used according to Kretz (1983)

\section{Table 1. Percentages of heavy minerals in the examined samples}

\section{Composition of the detrital garnets}

Garnets are important in the interpretation of the genesis of igneous and metamorphic rocks as (1) they are used for the pressure-temperature-time history of the host rock; (2) they are very good indicators of the parental rock type; and (3) they are useful for defining the metamorphic facies. "Pyrope-almandine-grossular" and "pyrope-almandine-spessartine" triangular diagrams (Méres 2008, 2009 - see Text-figs 6, 7) provide a good classification of garnets from the $\mathrm{UHP} / \mathrm{HP}$, granulite and amphibolite metamorphic facies, according to their chemical compositions.

To construct the original triangular diagrams, the compositions of garnets from various metamorphic conditions were plotted (Aubrecht et al. 2009; Méres 2008 , 2009). Representative analyses of the garnets from various rocks (kimberlites, garnet peridotites, UHP eclogites, eclogites, HP granulites, LP granulites, retrograde eclogites), were taken from the following papers: garnets from HP granulites in the Góry Sowie Mts. (O'Brien et al. 1997); garnets from peridotites, eclogites and granulites from the Bohemian Massif (Messiga and Bettini 1990; Nakamura et al. 2004; Seifert and Vrána 2005; Vrána et al. 2005; Medaris et al. 2006a,b; Janoušek et al. 2006, 2007; Racek et al. 2008); garnets from $\mathrm{HP}$ and UHP eclogites and

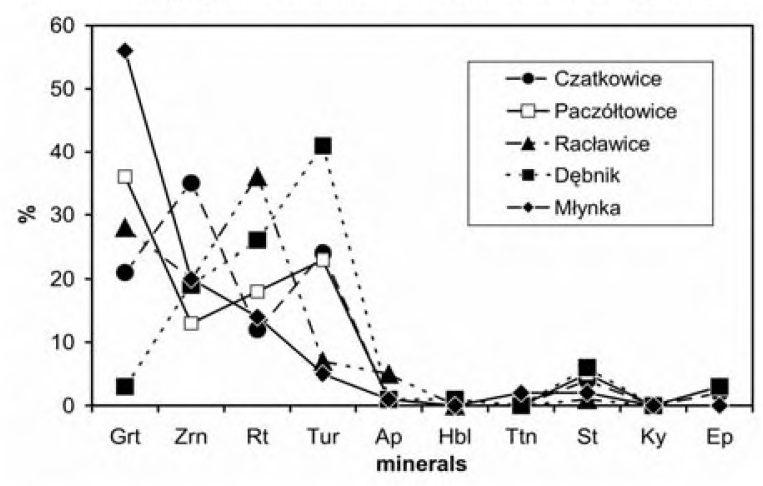

Text-fig. 4. Line diagram showing percentages of heavy minerals in the examined samples garnet peridotites from the Norway Western Gneiss Region (Krogh Ravna and Terry 2004); garnets from kimberlites (Schulze 1997); garnets from eclogites with inclusions of diamond (Schulze 1997); garnets from HP granulites, from UHP eclogites with inclusions of coesite and from garnet peridotites from the Saxonian Erzgebirge and Granulitgebirge (Massonne and Bautsch 2004). The resulting triangular diagram was divided to three sectors $-\mathrm{A}, \mathrm{B}, \mathrm{C}$, with the latter subdivided into the sectors $\mathrm{C} 1$ and $\mathrm{C} 2$ (see Text-figs 6 , 7, white fields): (A) garnets from high pressure (HP) and ultrahigh pressure (UHP) conditions; (B) garnets from HP eclogite and HP granulite facies conditions; and $(\mathrm{C})$ garnets from amphibolite facies conditions: Subsector Cl represents a transitional subgroup metamorphosed under transitional P-T conditions between the granulite and amphibolite facies conditions and Subsector C2 represents a subgroup of amphibolite facies conditions.

Electron microprobe analyses of the detrital garnets from Młynka (9 analyses from the grain cores), from Dębnik Quarry (9 analyses from the cores and rims), from Czatkowice (10 analyses from the cores), from Racławice (11 analyses from the cores) and from Paczóltowice ( 9 analyses from the cores) show significant variation in chemistry. Variation of garnet composition is mainly in the relative proportions of the pyrope, almandine, grossular, spessartine and uvarovite end-member components (Text-figs 6, 7; Table. 2). Chemical zoning across the profiles of the detrital garnets was not recognized; the garnets are homogenous (Text-fig. 5; Table 2).

The detrital garnets can be divided to six groups (within the previously defined sectors A, B and C) according to their composition (Text-figs 6, 7; Table 2):

(1) Detrital garnets with the highest contents of the pyrope molecule $(>70 \mathrm{~mol} \%$ ), with relatively low contents of almandine $(\sim 15 \mathrm{~mol} \%)$ and grossular $(\sim 12 \mathrm{~mol} \%)$ and a very low spessartine component $(<1 \mathrm{~mol} \%)$. Typical of this group is the presence of uvarovite $(0.7-1 \mathrm{~mol} \%)$. These types of garnets were 

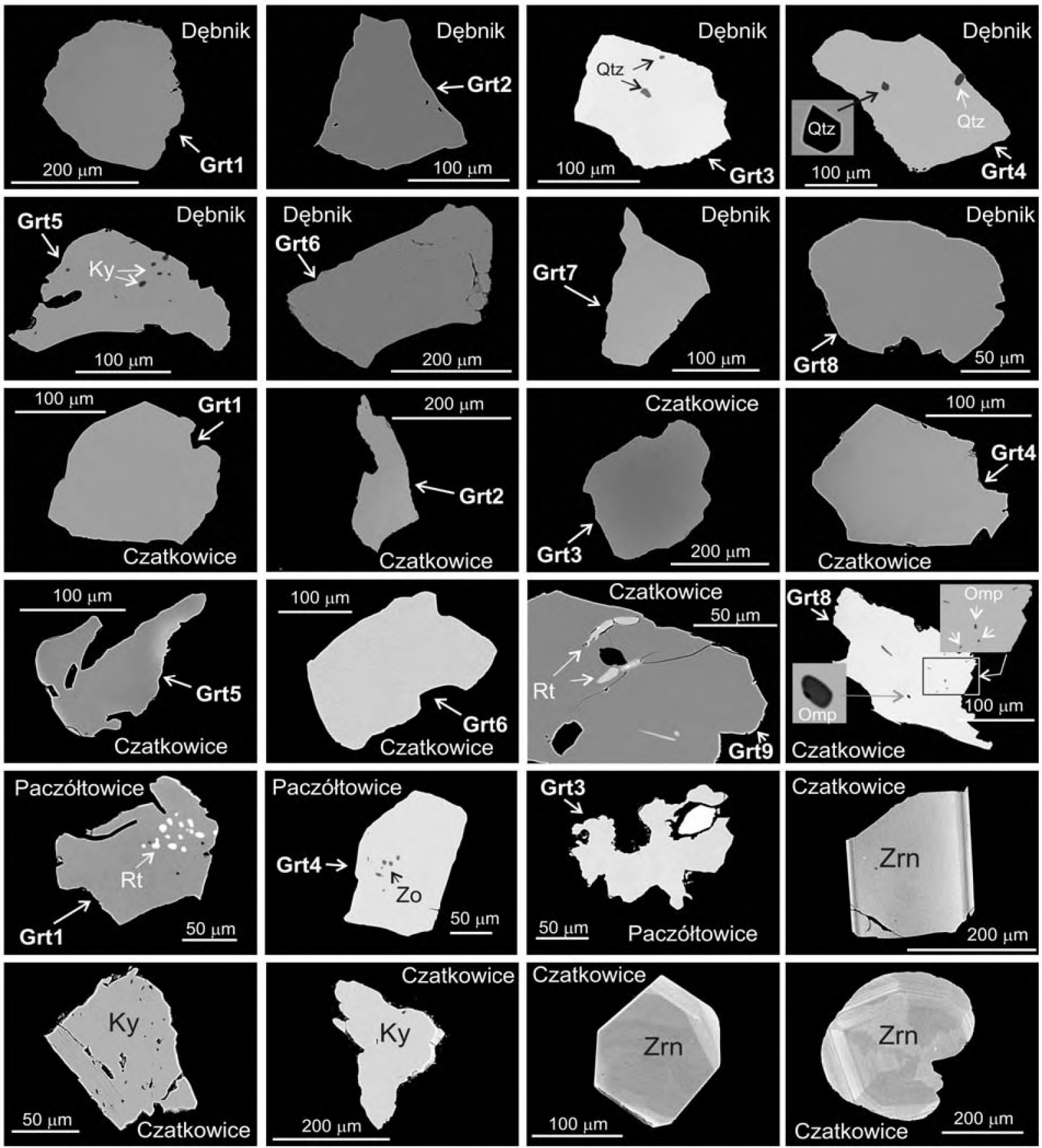

Text-fig. 5. Back-scattered electron (BSE) images of the detrital gamets, their inclusions, detrital kyanites and detrital zircons from sands and sandstones of the Cracow Region

identified at Mlynka, Dębnik Quarry and Czatkowice (Text-figs 6, 7, A sector).

(2) Detrital garnets with high contents of the pyrope molecule (40-56 mol \%), high almandine contents (35$45 \mathrm{~mol} \%$ ) and with high proportions of the grossular molecule $(15-31 \mathrm{~mol} \%)$. The spessartine content is less than $1 \mathrm{~mol} \%$. These garnets were identified at all the localities studied (Text-figs 6, 7, B sector, position around No. 2).
(3) Detrital garnets with lower contents of the pyrope molecule $(30-52 \mathrm{~mol} \%)$ than the previous groups, but with higher contents of almandine (50$60 \mathrm{~mol} \%)$, a low proportion of grossular $(\sim 5 \mathrm{~mol} \%)$ and very low contents of spessartine $(<2 \mathrm{~mol} \%)$ molecules. This type of garnet was found at all the localities studied (Text-figs. 6, 7, B sector, position around No. 3). 

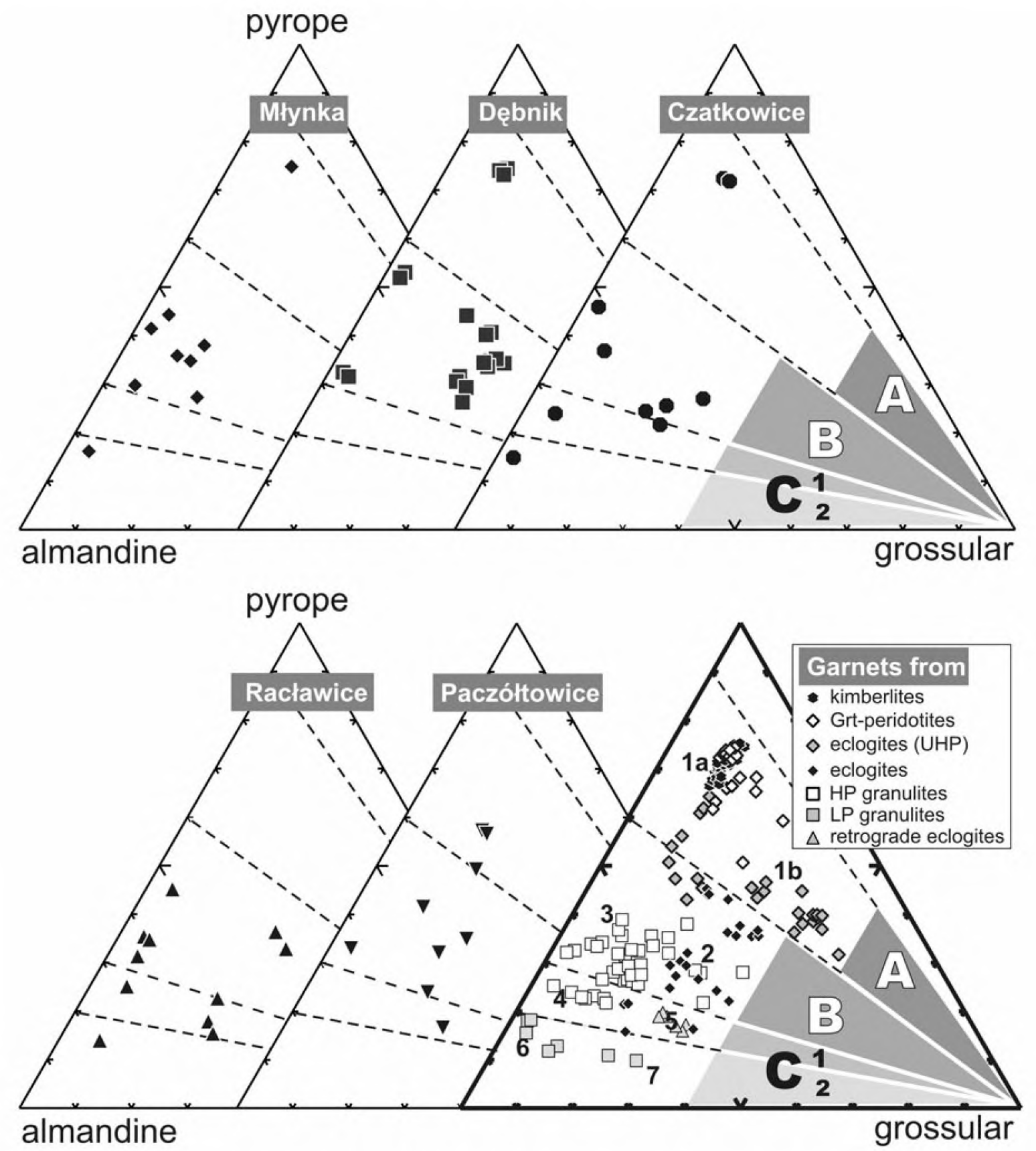

Text-fig. 6. Composition of the detrital gamets from the Middle Jurassic sands and sandstones of the Cracow Region and garnets from UHP/HP metamorphic rocks in the "pyrope-almandine-grossular" classification diagrams (Méres 2008, 2009): Explanations: Sector A. White field - gamets from UHP/HP conditions. Position around No. 1a - Grt derived from UHP eclogites, garnet peridotites and kimberlites. Position around No. 1b - Grt derived from UHP eclogites; Sector B. White field - garnets from eclogite and granulite facies conditions. Position around No. 2 - Grt derived from HP eclogites and HP mafic granulites. Position around No. 3-Grt derived from HP felsic and intermediate granulites; Sector $\mathrm{C}$. White field - garnets from amphibolite facies conditions: Sector $\mathrm{C} 1$ - transitional subgroup between granulite and high amphibolite facies conditions. Position around No. 4 - Grt derived from gneisses metamorphosed under P-T transitional to granulite and amphibolite facies conditions. Position around No. 5 - Grt derived from amphibolites metamorphosed under transitional P-T granulite to amphibolite facies conditions. Sector $\mathrm{C} 2$ - subgroup amphibolite facies conditions. Position around No. 6 - Grt derived from gneisses metamorphosed under amphibolite facies conditions. Position around No. 7 - Grt derived from amphibolites metamorphosed under amphibolite facies conditions. In the C2 subgroup Grt from many other sources integrate, e.g. Grt from igneous rocks (granitoids, syenites), Grt from HP/LT metamorphic rocks, Grt from contact-metamorphosed rocks. Grey fields - immiscibility gap of Grt end-members composition: A - from UHP/HP conditions, B - from eclogite and granulite facies conditions, $\mathrm{C}$ - from amphibolite facies conditions 
DETRITAL GARNETS FROM THE MIDDLE JURASSIC OF SOUTHERN POLAND

(4) Detrital garnets with high almandine contents (60$75 \mathrm{~mol} \%)$, low pyrope contents $(\sim 20 \mathrm{~mol} \%)$ and low contents of spessartine $(<10 \mathrm{~mol} \%)$. Contents of grossular were less than $6 \mathrm{~mol} \%$. A few garnets of this type were identified at the Czatkowice and Raclawice localities (Text-figs. 6, 7, C 1sector, position around No. 4).

(5) Detrital garnets with high almandine contents (40-60 mol \%), relatively low pyrope contents $(20-30$ mol \%) and very low contents of spessartine $(<3$ mol $\%$ ). Contents of grossular were $6-26 \mathrm{~mol} \%$. Only a few garnets of this type were identified at the Paczóltowice and Racławice localities (Text-figs. 6, 7, $\mathrm{C} 1$ sector, position around No. 5).

(6) Detrital garnets with high almandine contents (40-60 mol \%), low pyrope contents (10-15 mol \%) and high contents of spessartine $(9-28 \mathrm{~mol} \%)$. Contents of grossular were less than $6 \mathrm{~mol} \%$ (Text-figs 6, 7, C 2 sector, position around No. 6). Only three such detrital garnets grains were found, at the Mlynka, Czatkowice and Racławice localities.
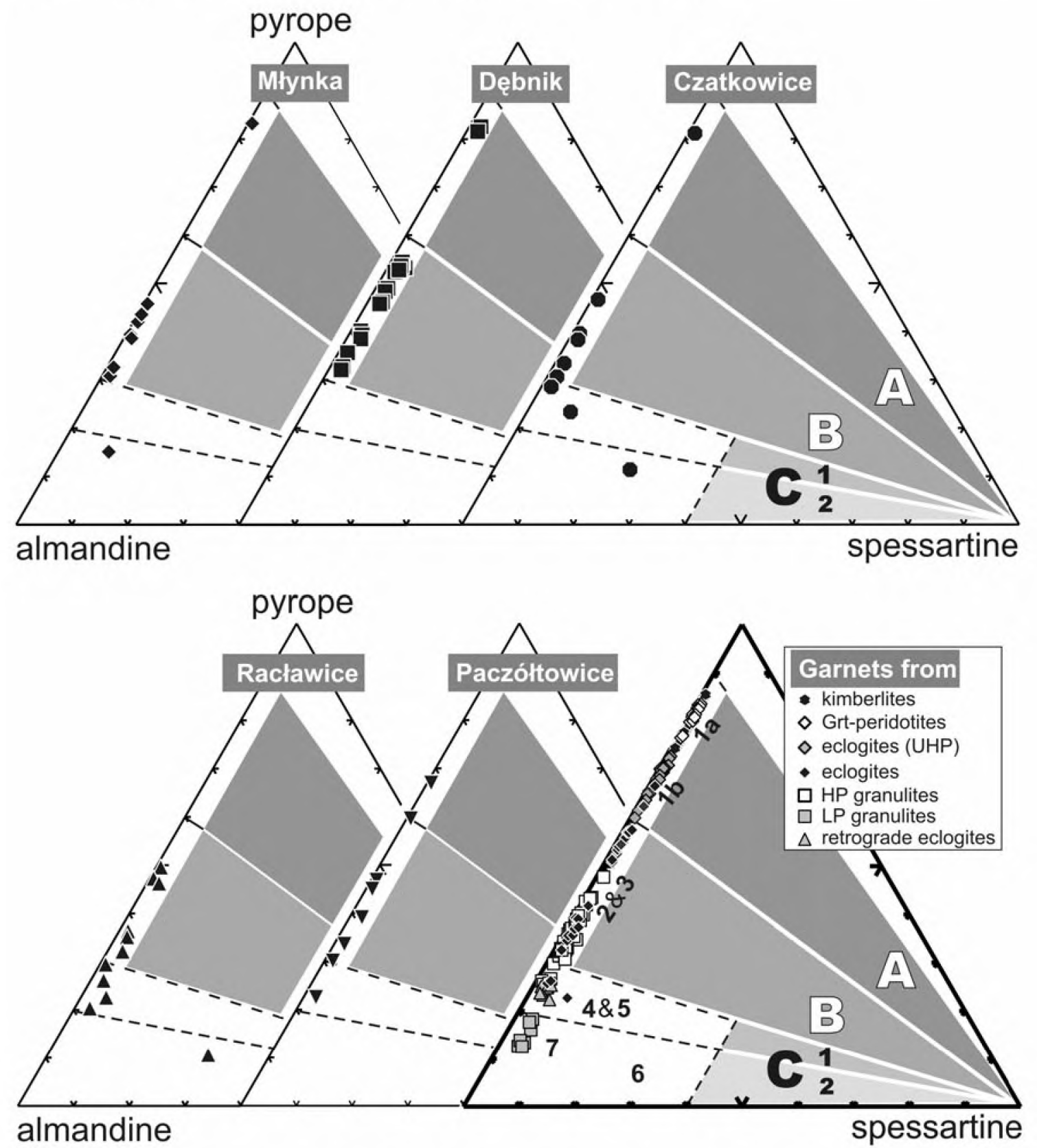

Text-fig. 7. Composition of the detrital garnets from the Middle Jurassic sands and sandstones of the Cracow Region and garnets from UHP/HP metamorphic rocks in the "pyrope-almandine-spessartine" classification diagrams (Méres 2008, 2009). For explanations see Text-fig. 6 


\begin{tabular}{|c|c|c|c|c|c|c|c|c|c|c|}
\hline locality & \multicolumn{4}{|c|}{ Młynka } & \multicolumn{4}{|c|}{ Dębnik } & \multicolumn{2}{|c|}{ Czatkowice } \\
\hline grain & Grt 2 c & Grt 3c & Grt $4 \mathrm{c}$ & Grt $7 \mathrm{c}$ & Grt 2 r & Grt $4 \mathrm{c}$ & Grt 5c & Grt $6 \mathrm{r}$ & Grt 2 c & Grt $6 \mathrm{r}$ \\
\hline Grt source & $\mathrm{A}$ & C 2-6 & B 3 & B 3 & B 2 & $\mathrm{A}$ & B 3 & B 2 & C 2-6 & B 3 \\
\hline $\mathrm{SiO}_{2}$ & 42.47 & 37.93 & 39.16 & 39.96 & 40.57 & 43.00 & 39.21 & 39.78 & 37.51 & 39.30 \\
\hline $\mathrm{TiO}_{2}$ & 0.17 & 0.02 & 0.01 & 0.03 & 0.00 & 0.00 & 0.00 & 0.00 & 0.00 & 0.00 \\
\hline $\mathrm{Al}_{2} \mathrm{O}_{3}$ & 21.56 & 21.38 & 21.99 & 22.43 & 23.00 & 22.12 & 22.40 & 22.07 & 21.16 & 22.19 \\
\hline $\mathrm{Cr}_{2} \mathrm{O}_{3}$ & 2.82 & 0.02 & 0.00 & 0.07 & 0.06 & 2.21 & 0.00 & 0.00 & 0.00 & 0.01 \\
\hline $\mathrm{Fe}_{2} \mathrm{O}_{3 \mathrm{calc}}$ & 0.55 & 0.14 & 0.18 & 0.36 & 0.04 & 0.18 & 0.55 & 0.00 & 0.00 & 0.00 \\
\hline $\mathrm{FeO}_{\mathrm{calc}}$ & 7.06 & 32.92 & 29.78 & 24.30 & 16.76 & 7.59 & 20.45 & 20.75 & 27.78 & 25.19 \\
\hline $\mathrm{MnO}$ & 0.41 & 4.00 & 0.72 & 0.42 & 0.43 & 0.45 & 0.54 & 0.49 & 10.34 & 0.46 \\
\hline $\mathrm{MgO}$ & 20.92 & 3.71 & 7.66 & 11.73 & 10.77 & 20.96 & 13.67 & 7.64 & 2.80 & 9.48 \\
\hline $\mathrm{CaO}$ & 4.81 & 1.40 & 2.08 & 1.69 & 9.46 & 4.68 & 1.19 & 9.59 & 0.86 & 3.07 \\
\hline \multirow[t]{2}{*}{ Total } & 100.76 & 101.52 & 101.58 & 100.98 & 101.09 & 101.19 & 98.01 & 100.31 & 100.46 & 99.69 \\
\hline & \multicolumn{10}{|c|}{ formula normalization to 12 oxygens } \\
\hline $\mathrm{Si}$ & 3.000 & 2.998 & 3.001 & 2.996 & 2.996 & 3.019 & 2.981 & 3.025 & 3.015 & 3.014 \\
\hline $\mathrm{Ti}$ & 0.009 & 0.001 & 0.000 & 0.001 & 0.000 & 0.000 & 0.000 & 0.000 & 0.000 & 0.000 \\
\hline $\mathrm{Al}$ & 1.795 & 1.992 & 1.986 & 1.981 & 2.002 & 1.831 & 2.007 & 1.977 & 2.004 & 2.005 \\
\hline $\mathrm{Cr}$ & 0.158 & 0.001 & 0.000 & 0.004 & 0.004 & 0.123 & 0.000 & 0.000 & 0.000 & 0.001 \\
\hline $\mathrm{Fe}^{3+}$ & 0.029 & 0.009 & 0.011 & 0.020 & 0.002 & 0.009 & 0.032 & 0.000 & 0.000 & 0.000 \\
\hline $\mathrm{Fe}^{2+}$ & 0.417 & 2.176 & 1.909 & 1.523 & 1.035 & 0.446 & 1.300 & 1.320 & 1.867 & 1.616 \\
\hline $\mathrm{Mn}$ & 0.024 & 0.268 & 0.047 & 0.027 & 0.027 & 0.027 & 0.035 & 0.031 & 0.704 & 0.030 \\
\hline $\mathrm{Mg}$ & 2.203 & 0.437 & 0.876 & 1.311 & 1.185 & 2.194 & 1.549 & 0.866 & 0.335 & 1.084 \\
\hline \multirow[t]{2}{*}{$\mathrm{Ca}$} & 0.364 & 0.119 & 0.171 & 0.136 & 0.749 & 0.352 & 0.097 & 0.781 & 0.074 & 0.252 \\
\hline & \multicolumn{10}{|c|}{$\mathrm{mol} \%$} \\
\hline almandine & 13.9 & 72.6 & 63.6 & 50.8 & 34.5 & 14.8 & 43.6 & 44.0 & 62.6 & 54.2 \\
\hline pyrope & 73.2 & 14.6 & 29.2 & 43.7 & 39.6 & 72.7 & 52.0 & 28.9 & 11.2 & 36.4 \\
\hline grossular & 10.9 & 3.9 & 5.7 & 4.5 & 24.9 & 10.9 & 3.2 & 26.1 & 2.5 & 8.4 \\
\hline spessartine & 0.8 & 8.9 & 1.6 & 0.9 & 0.9 & 0.9 & 1.2 & 1.0 & 23.6 & 1.0 \\
\hline uvarovite & 1.0 & 0.0 & 0.0 & 0.0 & 0.0 & 0.7 & 0.0 & 0.0 & 0.0 & 0.0 \\
\hline andradite & 0.3 & 0.0 . & 0.0 & 0.0 & 0.0 & 0.1 & 0.1 & 0.0 & 0.0 & 0.0 \\
\hline
\end{tabular}

$\mathrm{Fe}_{2} \mathrm{O}_{3 \mathrm{calc}}$ and $\mathrm{FeO}_{\text {calo }}$ calculated from stoichiometry, $\mathrm{c}$-core, $\mathrm{r}$ - rim, Grt source - position in classify diagrams (Text-figs 5 and 6 )

Table 2. Representative microprobe analyses of detrital garnets from the Middle Jurassic sand and sandstones of the Cracow-Wieluń Upland

\section{Inclusions in the detrital garnets}

In many of the detrital garnets minute inclusions ( $10 \mu \mathrm{m}$ ) of zoisite, quartz, rutile and ilmenite were recognized (Text-fig. 4). In the garnets with pyrope contents of $71.1 \mathrm{~mol} \%$ (Grt 8, Table 2) from Czatkowice, omphacite inclusions with a high proportion of jadeite were recognized (Text-fig. 5, 8, Table 3). In the detrital garnets with $52 \mathrm{~mol} \%$ of pyrope (Grt 5, Table 2) from Dębnik, kyanite inclusions were recognized (Text-fig. 5).

\section{DISCUSSION AND INTERPRETATION}

\section{Interpretation of the source rocks}

Comparision of the six groups of detrital garnets from the Middle Jurassic sands and sandstones of the Cracow Region and representative analyses of the garnets from various metamorphic rocks (Text-figs 6,7) shows that the detrital garnets were derived from various HP (UHP) metamorphic rocks:

The first group of detrital garnets (A), located in the Asector in the triangular diagrams, (Text-figs 6,7) shows similar compositions to the garnets (with diamond and coesite inclusions) from UHP eclogites, garnet peridotites and kimberlites. Specific for these detrital garnet are high pyrope contents ( $\sim 70 \mathrm{~mol} \%)$, the presence of uvarovite $(\sim 1 \mathrm{~mol} \%)$ and rare inclusions of omphacite (Text-fig. 5, Tables 2, 3). This indicates that the parental rocks of these detrital garnets were UHP eclogites or garnet peridotites.

The second group of detrital garnets (B2), located in the B sector around No. 2 in the triangular diagrams, was derived from HP (UHP) eclogites and HP mafic granulites.

The third group of detrital garnets (B3), located in the triangular diagrams around No. 3, were derived from $\mathrm{HP}$ 
DETRITAL GARNETS FROM THE MIDDLE JURASSIC OF SOUTHERN POLAND

\begin{tabular}{|c|c|c|c|c|c|c|c|c|c|c|}
\hline locality & \multicolumn{2}{|c|}{ Czatkowice } & \multicolumn{4}{|c|}{ Racławice } & \multicolumn{4}{|c|}{ Paczóltowice } \\
\hline grain & Grt $7 \mathrm{c}$ & Grt $8 \mathrm{c}$ & Grt $1 \mathrm{r}$ & Grt 2c & Grt $3 \mathrm{c}$ & Grt $8 \mathrm{c}$ & Grt 1 c & Grt $3 \mathrm{c}$ & Grt 4c & Grt $7 \mathrm{c}$ \\
\hline Grt source & C 1-5 & $\mathrm{A}$ & B 3 & C 2-6 & B 3 & B 2 & B 2 & B 2 & C $1-5$ & B 2 \\
\hline $\mathrm{SiO}_{2}$ & 39.86 & 42.69 & 39.46 & 37.84 & 40.35 & 40.30 & 41.65 & 40.26 & 38.92 & 42.16 \\
\hline $\mathrm{TiO}_{2}$ & 0.00 & 0.00 & 0.00 & 0.00 & 0.00 & 0.00 & 0.00 & 0.00 & 0.00 & 0.00 \\
\hline $\mathrm{Al}_{2} \mathrm{O}_{3}$ & 22.27 & 21.90 & 21.98 & 20.94 & 22.54 & 22.30 & 23.12 & 22.45 & 21.23 & 23.65 \\
\hline $\mathrm{Cr}_{2} \mathrm{O}_{3}$ & 0.00 & 2.33 & 0.03 & 0.02 & 0.16 & 0.03 & 0.00 & 0.03 & 0.00 & 0.08 \\
\hline $\mathrm{Fe}_{2} \mathrm{O}_{3 \mathrm{calc}}$ & 0.00 & 0.05 & 0.00 & 0.00 & 0.00 & 0.00 & 0.00 & 0.00 & 0.00 & 0.00 \\
\hline $\mathrm{FeO}_{\text {calc }}$ & 19.69 & 7.92 & 27.44 & 25.41 & 23.44 & 16.98 & 15.76 & 21.35 & 24.61 & 13.21 \\
\hline $\mathrm{MnO}$ & 0.46 & 0.39 & 0.82 & 12.10 & 1.09 & 0.31 & 0.29 & 0.39 & 0.73 & 0.32 \\
\hline $\mathrm{MgO}$ & 7.05 & 20.36 & 8.88 & 2.54 & 11.87 & 8.71 & 13.33 & 10.80 & 4.18 & 15.45 \\
\hline $\mathrm{CaO}$ & 11.34 & 5.02 & 1.89 & 1.85 & 1.75 & 11.47 & 6.87 & 4.59 & 10.00 & 6.28 \\
\hline \multirow[t]{2}{*}{ Total } & 100.67 & 100.67 & 100.49 & 100.71 & 101.19 & 100.09 & 101.03 & 99.88 & 99.66 & 101.16 \\
\hline & \multicolumn{10}{|c|}{ formula normalization to 12 oxygens } \\
\hline $\mathrm{Si}$ & 3.019 & 3.021 & 3.027 & 3.033 & 3.013 & 3.032 & 3.041 & 3.040 & 3.050 & 3.033 \\
\hline $\mathrm{Ti}$ & 0.000 & 0.000 & 0.000 & 0.000 & 0.000 & 0.000 & 0.000 & 0.000 & 0.000 & 0.000 \\
\hline $\mathrm{Al}$ & 1.988 & 1.826 & 1.988 & 1.978 & 1.984 & 1.977 & 1.990 & 1.998 & 1.961 & 2.006 \\
\hline $\mathrm{Cr}$ & 0.000 & 0.130 & 0.002 & 0.001 & 0.009 & 0.002 & 0.000 & 0.002 & 0.000 & 0.005 \\
\hline $\mathrm{Fe}^{3+}$ & 0.000 & 0.003 & 0.000 & 0.000 & 0.000 & 0.000 & 0.000 & 0.000 & 0.000 & 0.000 \\
\hline $\mathrm{Fe}^{2+}$ & 1.248 & 0.469 & 1.760 & 1.703 & 1.464 & 1.068 & 0.962 & 1.348 & 1.613 & 0.795 \\
\hline $\mathrm{Mn}$ & 0.030 & 0.023 & 0.053 & 0.821 & 0.069 & 0.020 & 0.018 & 0.025 & 0.048 & 0.020 \\
\hline $\mathrm{Mg}$ & 0.796 & 2.147 & 1.015 & 0.304 & 1.321 & 0.976 & 1.451 & 1.216 & 0.488 & 1.658 \\
\hline \multirow[t]{2}{*}{$\mathrm{Ca}$} & 0.920 & 0.381 & 0.155 & 0.159 & 0.140 & 0.925 & 0.538 & 0.372 & 0.839 & 0.484 \\
\hline & \multicolumn{10}{|c|}{$\mathrm{mol} \%$} \\
\hline almandine & 41.7 & 15.5 & 59.0 & 57.0 & 48.9 & 35.7 & 32.4 & 45.5 & 54.0 & 26.9 \\
\hline pyrope & 26.6 & 71.1 & 34.0 & 10.2 & 44.1 & 32.7 & 48.9 & 41.1 & 16.3 & 56.1 \\
\hline grossular & 30.7 & 11.7 & 5.2 & 5.3 & 4.6 & 30.9 & 18.1 & 12.5 & 28.1 & 16.3 \\
\hline spessartine & 1.0 & 0.8 & 1.8 & 27.5 & 2.3 & 0.7 & 0.6 & 0.8 & 1.6 & 0.7 \\
\hline uvarovite & 0.0 & 0.8 & 0.0 & 0.0 & 0.0 & 0.0 & 0.0 & 0.0 & 0.0 & 0.0 \\
\hline andradite & 0.0 & 0.0 & 0.0 & 0.0 & 0.0 & 0.0 & 0.0 & 0.0 & 0.0 & 0.0 \\
\hline
\end{tabular}

Table 2. continue. Representative microprobe analyses of detrital garnets from the Middle Jurassic sand and sandstones of the Cracow-Wielun Upland

felsic and intermediate granulites. HP metamorphic souree rocks were also indicated by rare inclusions of kyanite (Text-fig. 5).

The fourth group of detrital garnets (C1-4), located in the triangular diagrams around No. 4, were derived from LP granulites or gneisses metamorphosed under transitional P-T conditions to granulite and amphibolite facies.

The fifth group of detrital garnets (C1-5), located in the triangular diagrams around No. 5, were derived from retrograde eclogites or amphibolites, metamorphosed under transitional $\mathrm{P}-\mathrm{T}$ conditions to granulite and amphibolite facies.

The sixth group of detrital garnets (C2-6), located in the trianglar diagrams around No. 6, were derived from gneisses metamorphosed under amphibolite facies conditions. Such a detrital garnet composition was relatively rare.
Most of the detrital garnets from all the localities generally contain high contents of the pyrope molecule (30-73 mol \%) and, according to their chemical compositions, are classified in the triangular diagrams as garnets coming from HP/UHP conditions and garnets coming from HP eclogite and $\mathrm{HP}$ granulite facies conditions (Text-figs. 6, 7).

The inclusions in the detrital pyrope garnets also provide useful evidence of their provenance. The associated minerals in eclogites include pyrope garnet, omphacite, quartz (coesite), rutile, kyanite, phengite, and lawsonite (e.g. Carswell 1990; Best 2003; Liou et al. 2004). Omphacite is stable only in relatively high pressure metamorphic facies and is a major mineral component of UHP metamorphic rocks. It is therefore diagnostic of eclogite facies metamorphism (Desmons and Smulikowski 2004; Schmid et al. 2004).

UHP/HP source rocks are indicated mainly by occurrences of omphacite inclusions with high jadeite contents (Text-fig. 8) in the detrital pyrope garnets with high pyrope contents $(\sim 70 \mathrm{~mol} \%)$. Such pyrope contents are 


\begin{tabular}{|c|c|c|c|c|}
\hline grain & $\begin{array}{c}\text { Omp } \\
1\end{array}$ & $\begin{array}{c}\text { Omp } \\
2\end{array}$ & $\begin{array}{c}\text { Omp } \\
3\end{array}$ & $\begin{array}{c}\text { Omp } \\
4\end{array}$ \\
\hline $\mathrm{SiO}_{2}$ & 55.99 & 52.66 & 55.89 & 52.89 \\
\hline $\mathrm{TiO}_{2}$ & 0.09 & 0.12 & 0.08 & 0.10 \\
\hline $\mathrm{Al}_{2} \mathrm{O}_{3}$ & 12.18 & 14.03 & 12.37 & 13.93 \\
\hline $\mathrm{Cr}_{2} \mathrm{O}_{3}$ & 0.00 & 0.00 & 0.00 & 0.00 \\
\hline $\mathrm{FeO}$ & 4.24 & 7.77 & 3.84 & 7.17 \\
\hline $\mathrm{MnO}$ & 0.02 & 0.14 & 0.01 & 0.12 \\
\hline $\mathrm{MgO}$ & 7.97 & 7.46 & 7.82 & 7.65 \\
\hline $\mathrm{CaO}$ & 13.48 & 12.71 & 13.64 & 12.82 \\
\hline $\mathrm{Na}_{2} \mathrm{O}$ & 6.25 & 5.11 & 6.55 & 5.61 \\
\hline $\mathrm{K}_{2} \mathrm{O}$ & 0.00 & 0.00 & 0.00 & 0.00 \\
\hline Total & 100.24 & 100.01 & 100.22 & 100.30 \\
\hline & \multicolumn{4}{|c|}{ formula normalization to 6 oxygens } \\
\hline $\mathrm{Si}$ & 1.981 & 1.896 & 1.977 & 1.897 \\
\hline $\mathrm{Al}^{\mathrm{IV}}$ & 0.019 & 0.104 & 0.023 & 0.103 \\
\hline $\mathrm{Al}^{\mathrm{VI}}$ & 0.489 & 0.492 & 0.493 & 0.486 \\
\hline $\mathrm{Fe}^{3+}$ & 0.000 & 0.000 & 0.000 & 0.002 \\
\hline $\mathrm{Cr}$ & 0.000 & 0.000 & 0.000 & 0.000 \\
\hline $\mathrm{Ti}$ & 0.002 & 0.003 & 0.002 & 0.003 \\
\hline $\mathrm{Fe}^{2+}$ & 0.126 & 0.235 & 0.114 & 0.214 \\
\hline Mn & 0.001 & 0.004 & 0.000 & 0.004 \\
\hline $\mathrm{Mg}$ & 0.421 & 0.400 & 0.413 & 0.409 \\
\hline $\mathrm{Ca}$ & 0.511 & 0.490 & 0.517 & 0.493 \\
\hline $\mathrm{Na}$ & 0.429 & 0.357 & 0.449 & 0.391 \\
\hline $\mathrm{K}$ & 0.000 & 0.000 & 0.000 & 0.000 \\
\hline Total & 3.978 . & 3.982 . & 3.988 . & 4.001 \\
\hline
\end{tabular}

$\mathrm{Fe}^{3+}$ and $\mathrm{Fe}^{2+}$ calculated from stoichiometry

Table 3. Representative microprobe analyses of omphacite inclusions in the detrital garnets (Czatkowice locality, Grt8, Text-fig. 5) from the Middle Jurassic sand and sandstones of the Cracow-Wielun Upland

typical only of garnets from garnet peridotites, kimberlites and UHP eclogites with inclusions of coesite and diamond (Text-figs 6,7 ). The presence of kyanite and rutile inclusions (Text-fig. 5) in the detrital garnets with high pyrope contents also indicate their high pressure origin.

\section{Interpretation of the possible source area}

UHP metamorphic terranes consist of UHP continental gneiss, country-rock eclogite and lenses of mantle-derived peridotite. This HP/UHP rock association requires that slices of continental crust be subducted deeply into the mantle so that fragments of the overlying mantle-wedge can become entrained in the crust as peridotite lenses. The UHP terranes are subsequently exhumed and erosion exposes deeper levels of the orogen (Ernst and Liou 2000; Liou et al. 2004).
Such metamorphosed complexes are known in the European Variscides (e.g. Dora Maira Massif of the Western Alps, Moldanubian Zone of the Bohemian Massif, Massif Central) and in the Western Gneiss Region of the Norwegian Caledonides (e.g. Liou et al. 2004).

The provenance of the studied detrital garnets is interesting in the context of the position of the CracowWielun Upland. It is situated in the Brunovistulian Zone, which is a terrane consolidated in Neoproterozoic time and only weakly metamorphosed in the Hercynian orogeny (Żelaźniewicz et al. 2009). Most of this terrane is covered by younger sediments but there are no borehole or outcrop data to provide evidence of the presence of UHP/HP rocks (e.g. granulites and eclogites). The nearby Bialsko-Andrychów Massif (see Textfig. 9) does not contain any granulites or eclogites. (fig. 9)

The only known potential primary sources occur in Hercynian zones west of the Brunovistulian Zone, e.g. the Moldanubian Zone and the Lugic Zone (Western Sudetes). Metamorphic rocks in the Moldanubian Zone of the Bohemian Massif (garnet peridotites, garnet pyroxenites, kyanite eclogites and granulites) commonly contain pyrope-rich garnets (Medaris et al. 1995a, b, 1998, 2005, 2006a, b; Nakamura et al. 2004; O'Brien and Vrána 1995; O'Brien et al. 1997; Scharbert and Carswell 1983). There are also two more proximal occurrences of granulites and eclogites - the Góry Sowie Block and the Śnieźnik area complex in the Western Sudetes (Oberc 1972; Smulikowski 1967; Kryza et al. 1996; O'Brien et al. 1997). These are, however, too

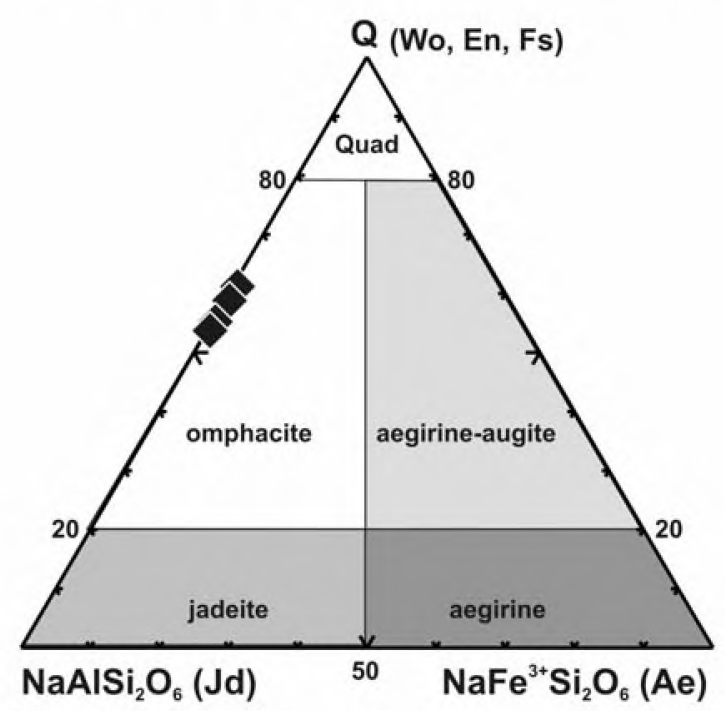

Text-fig. 8. Composition of omphacite inclusions (Table 3) in the detrital garnets (Grt8, Text-fig. 5) from the Czatkowice locality. Nomenclature of the Ca$\mathrm{Mg}-\mathrm{Fe}$ and Na pyroxenes with accepted names according to IMA classification (Morimoto et al. 1989). Quad represents the Ca-Mg-Fe pyroxene area 


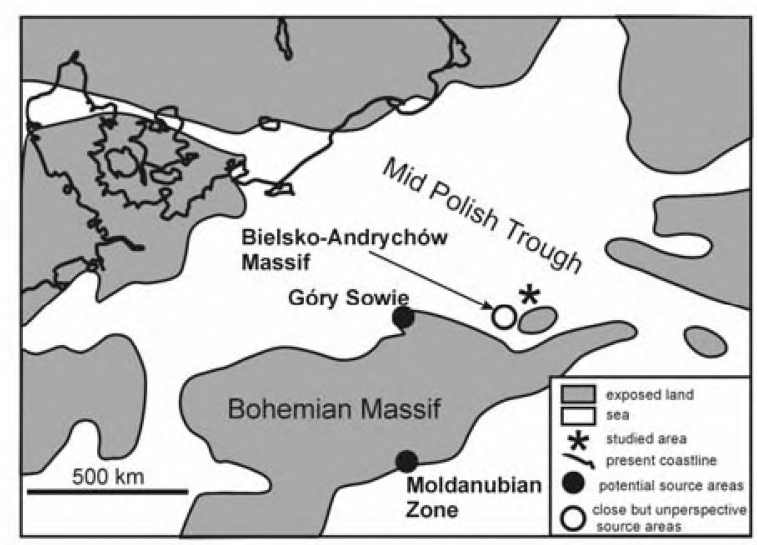

Text-fig. 9. Potential source areas on palaeogeographical map of Middle Callovian (Thierry and Barrier 2000)

small to be a regionally important source of clastic material in the Cracow-Wieluń Upland. Nevertheless, Biernacka and Józefiak (2009) considered the granulitic block of Góry Sowie as the main source of pyropealmandine garnets in Turonian sandstones in the North Sudetic Basin. They argued that the areal extent of this unit in the Mesozoic was larger, as a large part of it is covered with younger, Cenozoic sediments.

In order to evaluate a possible reworking of the detrital material, it is necessary to mention that exotic pyrope-almandine garnets were also reported from the Carboniferous of the Moravo-Silesian Culm basin (Otava and Sulovský 1998; Otava et al. 2000; Čopjaková et al. 2001, 2005; Hartley and Otava 2001). Some granulitic pebbles were also found in the Carboniferous sediments of the Upper Silesia Coal Basin (Paszkowski et al. 1995). In the Carboniferous clastics of the Moravo-Silesian Zone, the authors invariably derive the clastic material from the Moldanubian Zone of the Bohemian Massif (Paszkowski et al. 1995; Hartley and Otava 2001). The Upper Carboniferous clastics of the Upper Silesia Coal Basin cannot be completely excluded from consideration, since Łydka (1955) claims that some sandstones from the Libiąż Beds contain 4.3 vol. \% of garnets, of which some are high-pyrope garnets (personal communication Mariusz Paszkowski, 2010). Przybyłowicz (1958) interpreted her results from the Jurassic of the Cracow-Wielun Upland as indicating resedimentation from the "Buntsandstein" (Lower Triassic sandstones of the Germanic Triassic Basin). We consider the probability of complete reworking of our material from older clastics as low, albeit the ZTR index of some samples shows relative depletion in less stable minerals. Moreover, all the possible sources known to date (Moldanubian Zone, Góry Sowie, Carboniferous sediments of
Silesia) are surrounded by crystalline complexes in which almandine garnets are dominant (e.g. in the Góry Sowie Mts. only a restricted part of the crystalline complexes contains pyrope-almandine garnets. The rest is almandine-dominated - see Biernacka and Józefiak 2009). Heavy mineral spectra transported from these distal sources would be enriched in almandine. The source rocks were then most probably primary crystalline complexes of lower crust to mantle origin, outcrops of which were not very far distant from the area of deposition. Perhaps verification of the subsurface extent of the Góry Sowie Massif would shed more light on this problem (cf. Biernacka and Józefiak 2009).

In the context of the presence of the pyrope-almandine garnets in the Polish Jurassic platform cover, it is important to note its relationship with the Tethyan realm rimming the platform to the south. Pyrope-rich garnets are absent in the crystalline rocks of the West Carpathian internides (Central and Inner Western Carpathians. (Aubrecht and Méres 2000) but they are ubiquitous in the Outer Western Carpathians, which are very close to the Polish Platform. Pyrope-almandine garnets are typical of the Jurassic of the Pieniny Klippen Belt (Aubrecht and Méres 1999, 2000). Similar garnets were reported from the Cretaceous to Paleogene sediments of the Carpathian Flysch Zone (Otava et al. 1997, 1998; Salata 2004; Oszczypko and Salata 2005; Grzebyk and Leszczyński 2006). The data from the Flysch Zone are not restricted solely to heavy minerals; exotic granulitic pebbles (one of the potential source rocks) were also reported from the Silesian Unit by Wieser (1985). Based on the exotic pebbles from the Silesian Cordillera, it was inferred that it was composed of Hercynian crystalline complexes: granulites with eclogites in the west and weakly metamorphosed Neoproterozoic complexes in the east (Paszkowski et al. 1995; Poprawa et al. 2006), i.e. it was most probably derived from the Moldanubian/ Brunovistolian contact area. It is also consistent with the earlier interpretations of Aubrecht and Méres (1999, 2000) who derived the Pienidic (Oravic) crustal segment from the Moldanubian Zone.

\section{CONCLUSIONS}

(1) Heavy mineral analysis of the Middle Jurassic sands and sandstones of the Cracow Region shows a predominance of garnets and high amounts of zircon, rutile and tourmaline. These main heavy minerals are accompanied by subordinate amounts of staurolite, apatite, kyanite, titanite, hornblende and epidote. 
(2) The majority of the detrital garnets contain high contents of the pyrope molecule and their composition shows that they were derived mainly from a high(ultrahigh-) pressure metamorphic rocks (garnet peridotite, eclogite and granulite). This is also supported by inclusions of omphacite and kyanite.

(3) Similar rocks most probably formed the original crustal segments of the Outer Carpathians (Czorsztyn Ridge, Magura Cordillera, Silesian Cordillera).

(4) The Cracow-Wielun Upland is situated upon the Brunovistulian Zone, which was only weakly metamorphosed in the Hercynian orogeny and there are no data to provide evidence of the presence of $\mathrm{UHP} / \mathrm{HP}$ rocks. The nearby Bialsko-Andrychów Massif does not contain any granulites or eclogites.

(5) The terrane which seems to be most similar to the inferred source area is the Moldanubian Zone of the Bohemian Massif but this is too distant from the Cracow-Wielun Upland to be considered. Between the Moldanubian potential sources and the CracowWielun Upland there are terranes which contain predominantly almandine garnets. Any pyrope-almandine garnet-rich material would be diluted by almandine garnets, when transported from such a distance. Less distant are the Góry Sowie Mts., which incorporate UHP/HP metamorphic rocks, but the exposed areal extent of these rocks is too small. However, it is possible that larger portions of these metamorphic rocks are buried beneath the Cenozoic cover and might represent the source area.

(6) Although similar garnets were also reported from younger deposits (e.g. Carboniferous, Cretaceous), the possibility of complete reworking of the exotic garnets from older sediments is very low.

(7) The source area therefore remains unknown. Most probably it was formed by primary crystalline complexes of lower crust to mantle origin, outcrops of which were not far distant from the area of deposition.

\section{Acknowledgements}

The authors thank the Slovak Research and Development Agency (APVV) for the grants under the contracts APVV 0571-06, APVV 0465-06 and VEGA 1/0274/10. Dr. Mariusz Paszkowski provided unpublished information on garnets in
Upper Carboniferous rocks. Comments and useful new references of the reviewers of Prof. Dr. Bronislaw Andrzej Matyja and Dr. Krzysztof Nejbert (both from Warsaw University) helped to considerably improve the quality of the manuscript. Christopher J. Wood has made extensive linguistic corrections to the paper.

\section{REFERENCES}

Aubrecht, R. 1993. Clastic admixture in Dogger crinoidal limestones of Czorsztyn Unit. Geologica Carpathica, 44, 105-111.

Aubrecht, R. 2001. Jurassic heavy mineral distribution provinces of the Western Carpathians. Mineralia Slovaca, 33 , 473-486.

Aubrecht, R. and Méres, Š. 1999. Possible Moldanubic provenance of the Pieniny Klippen Belt crystalline basement deduced from detrital garnets. Carpathian Geology 2000 symp., Smolenice, $11^{\text {th }}-14^{\text {th }}$ Oct. 1999. Geologica Carpathica, 50 (special issue), 13-14.

Aubrecht, R. and Méres, $\breve{S}$. 2000. Exotic detrital almandinepyrope garnets in the Jurassic sediments of the Pieniny Klippen Belt and Tatric Zone: where did they come from? Mineralia Slovaca, 32, 17-28.

Aubrecht, R., Méres, Š., Sýkora, M. and Mikuš, T. 2009. Provenance of the detrital garnets and spinels from the Albian sediments of the Czorstyn Unit (Pieniny Klippen Belt, Western Carpathians, Slovakia). Geologica Carpathica, 60, 463-483.

Best, M.G. 2003. Igneous and metamorphic petrology. WileyBlackwell, 1-729. [2 $2^{\text {nd }}$ ed.]

Biernacka, J. and Józefiak, M. 2009. The Eastern Sudetic Island in the Early-to-Middle Turonian: evidence from heavy minerals in the Jerzmanice sandstones, SW Poland. Acta Geologica Polonica, 59, 545-565.

Carswell, D.A. 1990. Eclogites and the eclogite facies: Definitions and classifications, In: D.A. Carswell (Ed.), Eclogite facies rocks. Glasgow, Blackie, pp. 1-13.

Čojaková, R., Sulovský, P. and Otava, J. 2001. Utilization of detrital garnet chemistry for determination of the provenance and lithostratigraphy of the Culm of Drahany Upland. Mineralia Slovaca, 33, 509-511. [In Czech]

Čopjaková, R., Sulovský, P. and Paterson, B.A. 2005. Major and trace elements in pyrope-almandine garnets as sediment provenance indicators of the Lower Carboniferous Culm sediments, Drahany Uplands, Bohemian Massif. Lithos, 82, 81-70.

Dembicz, K., Praszkier, T., Glowniak, E. and Matyja, B.A., 2006. Stop B1.1 - Młynka Quarry, Callovian to Middle Oxfordian succession. In: A. Wierzbowski, R. Aubrecht, J. Golonka, J. Gutowski, M. Krobicki, B.A. Matyja, G. Pieńkowski and A Uchman (Eds), Jurassic of Poland and ad- 
jacent Slovakian Carpathians. Field trip guidebook of $7^{\text {th }}$ International Congress on the Jurassic System, pp. 138141. Warszawa.

Desmons, J. and Smulikowski, W. 2004. A systematic nomenclature for metamorphic rocks: High P/T metamorphic rocks. Recommendation by the IUGS Subcommission on the Systematics of Metamorphic Rocks: (SCMR website www.bgs.ac.uk/SCMR).

Dżulyński, S. 1950. Littoral deposits of the Middle Jurassic South of Krzeszowice. Rocznik Polskiego Towarzystwa Geologicznego, 19, 387-400. [In Polish with English summary]

Ernst, W.G. and Liou, J.G. (Ed.) 2000. Ultrahigh-pressure metamorphism and geodynamics in collision-type orogenic belts. Final Report of the Task Group III-6 of the International Litosphere Project. Geological Society of America, Columbia, 4, 1-293.

Faupl, P. 1975. Kristallinvorkommen und terrigene Sedimentgesteine in der Grestener Klippenzone (Lias-Neokom) von Ober und Niederösterreich. Ein Beitrag zur Herkunft und Genese. Jahrbuch der Geologischen Bundesanstalt, $118,1-74$.

Giżejewska, M. and Wieczorek, J. 1976. Remarks on the Callovian and Lower Oxfordian of the zalas area (Cracow Upland, Southern Poland). Bulletin de l'Academia Polonaise des Sciences, Série des Sciences de la Terre, 24, 167175 .

Grzebyk, J. and Leszczyński, S. 2006. New data on heavy minerals from the Upper Cretaceous-Paleogene flysch of the Beskid Śląski Mts. (Polish Carpathians). Geological Quarterly, 50, 265-280.

Hansley, P. 1987. Petrologic and experimental evidence for the etching of garnets by organic acids in the Upper Jurassic Morisson Formation, Northwestern New Mexico. Journal of Sedimentary Petrology, 57, 666-681.

Hartley, A.J. and Otava J. 2001. Sediment provenance in a deep marine foreland basin: the Lower Carboniferous Culm Basin, Czech Republic. Journal of the Geological Society, London, 158, 137-150.

Hoffmann, M. and Gradziński, M. 2004. Facies variation in Callovian deposits of the Cracow region (southern Poland) as an effect of basement topography and sensedimentary tectonic activity. In: L. Pena dos Reis, P. Callapez and P. Dinis (Eds): $23^{\text {rd }}$ Meeting of Sedimentology, Abstract Book. International Association of Sedimentologists, Coimbra, p. 144.

Hubert, J.F. 1962. A zircon-tourmaline maturity index and the interdependence of the composition of heavy mineral assemblages with the gross composition and texture of sandstones. Journal of Sedimentary Petrology, 32, 440450.

Janoušek, V., Gerdes, A., Vrána, S., Finger, F., Erban, V., Friedl, G. and Braithwaite, C.J.R. 2006. Low-pressure Gra- nulites of the Lišov Massif, Southern Bohemia: Viseán Metamorphism of Late Devonian Plutonic Arc Rocks. Journal of Petrology, 47, 705-744.

Janoušek, V., Krenn, E., Finger, F., Míková, J. and Frýda, J. 2007. Hyperpotassic granulites from the Blanský les Massif (Moldanubian Zone, Bohemian Massif) revisited. Journal of Geosciences, 52, 73-112.

Kopik, J. 1997. Lithostratigraphy and lithofacies. Formal and informal lithostratigraphic units. Polish Jura. Prace Państwowego Instytutu Geologicznego, 153, 263 pp. [In Polish]

Kretz, R. 1983. Symbols for rock forming minerals, American Mineralogist, 68, 277-279.

Krogh Ravna, E.J. and Terry, M.P. 2004. Geothermobarometry of UHP and HP eclogites and schists - an evaluation of equilibria among garnet-clinopyroxene-kyanite-phengite-coesite/quartz. Journal of Metamorphic Geology, 22 , $579-592$.

Krysowska, M. 1960. Heavy mineral assemblages in Brown Jurassic deposits from Krzeszowice. Biuletyn Instytutu Geologicznego, 152, 289-320. [In Polish]

Krysowska, M. 1962. Petrographical analysis of the Middle Jurassic formations from Rzeszotary. Rocznik Polskiego Towarzystwa Geologicznego, 32, 565-578. [In Polish]

Kryza, R., Pin, C. and Vielzeuf, D. 1996. High-pressure granulites from the Sudetes (south-west Poland): evidence of crustal subduction and collisional thickening in the Variscan Belt. Journal of Metamorphic Geology, 14, 531546.

Liou, J.G., Tsujimori, T., Zhang, R.Y., Katayama, I. and Maruyama, S. 2004. Global UHP metamorphism and continental subduction/collision: the Himalayan model. International Geology Review, 46, 1-27.

Loziński, J. 1956. Heavy minerals of the Aalenian flysch sandstones in the Pieniny Klippen Belt. Acta Geologica Polonica, 6, 17-23. [In Polish]

Loziński, J. 1957. Comparison of heavy mineral assemblages from the Podhale Flysch, Flysch Aalenian in the Pieniny Klippen Belt and the Jurassic exotics from Bachowice. Rocznik Polskiego Towarzystwa Geologicznego, 26, 157164. [In Polish]

Loziński, J. 1966. Detritic minerals in flysch sandstones of the Pieniny Klippen Belt and adjacent neighbouring. Prace Geologiczne PAN, 37, 1-57. [In Polish]

Łydka, K. 1955. Petrographic studies concerning the Permo-Carboniferous of the Cracow region. Biuletyn Instytutu Geologicznego, 97, 123-215. [In Polish with English summary] Matyszkiewicz, J. and Krajewski, M. 2007. Lithology and facies variation of the Upper Jurassic limestones of Szklarka and Będkowka valleys. Tomy Jurajskie, 4, 87-93. [In Polish]

Massonne, H.J. and Bautsch, H.J. 2004. Ultrahigh and High Pressure Rocks of Saxony. In: $32^{\text {nd }}$ IGC, Florence - Italy, 
August 20-28, 2004, Field Trip Guide Book - B21, 2, 136.

Medaris, L.G., Jr., Beard, B.L., Johnson, C.M., Valley, J.W., Spicuzza, M.J., Jelínek, E. and Mísař, Z. 1995a. Garnet pyroxenite and eclogite in the Bohemian Massif: Geochemical evidence for Variscan recycling of subducted lithosphere. Geologische Rundschau, 84, 489-505.

Medaris, L.G., Jr., Jelínek, E. and Mísař, Z. 1995b. Czech eclogites: Terrane settings and implications for Variscan tectonic evolution of the Bohemian Massif. European Journal of Mineralogy, 7, 7-78.

Medaris, L.G., Fournelle, J.H., Ghent, E.D., Jelínek, E. and Mísař, Z. 1998. Prograde eclogites in the Gföhl Nappe, Czech Republic: new evidence on Variscan high-pressure metamorphism. Journal of Metamorphic Geology, 16, 563-576.

Medaris, L.G., (Jr), Wang, H., Jelínek, E., Mihaljevič, M. and Jakeš, P. 2005. Characteristics and origins of diverse Variscan peridotites in the Gföhl nappe, Bohemian Massif, Czech Republic. Lithos, 82, 1-23.

Medaris (Jr) L.G., Beard, B.L. and Jelínek, E. 2006a. MantleDerived, UHP Garnet Pyroxenite and Eclogite in the Moldanubian Gföhl Nappe, Bohemian Massif: A Geochemical Review, New P-T Determinations, and Tectonic Interpretation. International Geological Reviews, 48, 765-777.

Medaris (Jr) L. G., Ghent, E. D., Wang, H. F., Fournelle, J. H., and Jelínek, E. 2006b. The Spačice eclogite: Constraints on the P-T-t history of the Gföhl granulite terrane, Moldanubian Zone, Bohemian Massif. Mineralogy and Petrology, 86, 203-220.

Méres, $\breve{S}$. 2008. Garnets - important information resource about source area and parental rocks of the siliciclastic sedimentary rocks. In: Jurkovič, L. (Ed.), Conference „Cambelove dni 2008“, Comenius Univ. Bratislava, Abstract book, 37-43. [In Slovak with English abstract]

Méres, Š. 2009. Express identification of the detrital garnets from UHP/HP metamorphic rocks using simple triangle diagrams prp-alm-grs and prp-alm-sps. In: Micro-Analysis, Processes, Time - MAPT, $30^{\text {th }}$ August $-4^{\text {th }}$ September 2009, Univ. Edinburgh, UK: Mineralogical Society, 134135.

Messiga, B. and Bettini E. 1990. Reactions behaviour during kelyphite and symplectite formation: a case study of mafic granulites and eclogites from the Bohemian Massif. European Journal of Mineralogy, 2, 125-144.

Morimoto, N., Fabries, J., Ferguson, A.K., Ginzburg, I.V., Ross, M., Seifeit, F.A. and Zussman, J. 1989. Nomenclature of pyroxenes. Canadian Mineralogist, 27, 143-156.

Morton, A.C. 1987. Influences of provenance and diagenesis on detrital garnet suites in the Paleocene Forties Sandstone, Central North Sea. Journal of Sedimentary Petrology, 57, 1027-1032.

Nakamura, D., Svojtka, M. Naemura, K. and Hirajima, T.
2004. Very high-pressure ( $>4 \mathrm{GPa}$ ) eclogite associated with the Moldanubian Zone garnet peridotite (Nové Dvory, Czech Republic). Journal of Metamorphic Geology, 22, 593-603.

Oberc, J. 1972. Geological structure of Poland. Tectonics - 2. Wydawnictwa Geologiczne; Warszawa, 1-307. [In Polish]

O'Brien, P.J. and Vrána, S. 1995. Eclogites with a short-lived granulite facies overprint in the Moldanubian Zone, Czech Republic: petrology, geochemistry and diffusion modeling of garnet zoning. Geologische Rundschau, $\mathbf{8 4}$, 473-488.

O’Brien, P.J., Kröner, A., Jaeckel, P., Hegner, E., Żelazniewicz, A. and Kryza, R. 1997. Petrological and isotopic studies on Paleozoic high-pressure granulites, Góry Sowie Mts, Polish Sudetes. Journal of Petrology, 38, 433-456.

Ogg, J.G., Steiner, M.B., Wieczorek, J. and Hoffmann, M. 1991. Jurassic magnetostratigraphy, 4. Early Callovian through Middle Oxfordian of the Kraków Uplands (Poland). Earth and Planetary Science Letters, 104, 488504.

Oszczypko, N. and Salata, D. 2005. Provenance analyses of the Late Cretaceous - Palaeocene deposits of the Magura Basin (Polish Western Carpathians) - evidence from a study of the heavy minerals. Acta Geologica Polonica, 55, 237267.

Otava, J., Krejči, O. and Sulovský, P. 1997. The first results of study of garnet chemistry from the sandstones of the Rača Unit of the Magura Flysch. Geologický výzkum Moravy a Slezska v r. 1996, 39-42. [In Czech]

Otava, J. and Sulovský, P. 1998. Detrital garnets and chromites from the Ksiaz Formation, Swiebodzice Depression: implications for the Variscan evolution of Sudetes. Geolines, 6, 49-50.

Otava, J., Sulovský, P. and Krejčí, O. 1998. The results of the chemistry of the detrital garnets from the Cretaceous sediments of the Rača Unit, Magura Group. Geologický výzkum Moravy a Slezska v r. 1997, 10-12. [In Czech]

Otava, J., Sulovský, P. and Čopjaková, R. 2000. Changes in provenance of greywackes from the Drahany Culm Basin: statistical evaluation. Geologický výzkum Moravy a Slezska v r. 1999, 94-98. [In Czech]

Paszkowski, M., Jachowicz, M., Michalik, M., Teller, L., Uchman, A. and Urbanek Z. 1995. Composition, age and provenance of gravel-sized clasts from the Upper Carboniferous of the Upper Silesia Coal Basin (Poland). Studia Geologica Polonica, 108, 45-127.

Przybylowicz, T. 1958. Petrographic studies of clastic Jurassic rocks of the Cracow region. Archiwum mineralogiczne, 22, 153-186. [In Polish with English summary]

Racek, M., Štípská, P. and Powell, R. 2008. Garnet-clinopyroxene intermediate granulites in the St. Leonhard mas- 
DETRITAL GARNETS FROM THE MIDDLE JURASSIC OF SOUTHERN POLAND

sif of the Bohemian Massif: ultrahigh-temperature metamorphism at high pressure or not? Journal of Metamorphic Geology, 26, 253-271.

Salata, D. 2004. Detrital garnets from the Upper CretaceousPaleogene sandstones of the Polish part of the Magura Nappe and the Pieniny Klippen Belt: chemical constraints. $A n$ nales Societatis Geologorum Poloniae, 74, 351-364.

Scharbert, H.G., and Carswell, D.A. 1983. Petrology of garnetclinopyroxene rocks in a granulite-facies environment, Bohemian massif of Lower Austria. Bulletin of Mineralogy, 106, 761-774.

Schmid, R., Fettes, D., Harte, B., Davis, E., Desmons, J., Meyer-Marsilius, H-J. and Siivola, J. 2004. A systematic nomenclature for metamorphic rocks. 1. How to name a metamorphic rock. Recommendation by the IUGS Subcommission on the systematics of metamorphic rocks (SCMR website www.bgs.ac.uk/SCMR).

Schulze, D.J. 1997. The significance of eclogite and Cr-poor megacryst garnets in diamond exploration. Exploration and Mining Geology, 6, 349-366.

Seifert, A.V. and Vrána, S. 2005. Bohemian garnet. Bulletin of Geosciences, 80, 113-124.

Smulikowski, K. 1967. Eclogites of the Znieznik Mts. in the Sudetes. Geologica Sudetica, 3, 7-180.

Štelcl, J., Schmidt, J., Svoboda, L. and Novotný, M. 1972. Notes on the petrography of autochthonous Paleozoic, Mesozoic and Paleogene in the basement of the Carpathian Foredeep and Flysch Belt in southern Moravia. Folia Facultatis Scientiarum Naturalium Universitatis
Purkynianae Brunenesis, 13, Geologia 23, 2, 3-106. [In Czech]

Štelcl, J., Svoboda, L., Schmidt, J. and Zádrapa, K. 1977. Notes on the petrography of autochthonous Paleozoic and Mesozoic in the platform basement of the Carpathian Foredeep and Flysch Belt (sections, „SOUTH“" and „CENTRE“). Folia Facultatis Scientiarum Naturalium Universitatis Purkynianae Brunenesis, 18, Geologia 29, 14, 5-120. [In Czech]

Thierry, J. and Barrier, E., Eds., 2000. Map 9. Middle Callovian. In: Dercourt, J., Gaetani, M., Vrielynck, B., Barrier, W., Biju-Duval, B., Brunet, M.F., Cadet, J.P., Crasquin, S. and Sandulescu, M. (Eds), Atlas Peri-Tethys Palaeogeographical Maps. Commission for the Geologic Map of the World; Paris.

Vrána, V., Štědrá, V. and Fišera, M. 2005. Petrology and geochemistry of the Běstvina granulite body metamorphosed at eclogite facies conditions, Bohemian Massif. Journal of Czech Geological Society, 50, 95-106.

Wieser, T. 1985. Some remarks on the sedimentation, composition and provenance of exoticstern Polish Carpathians flysch formations. In: T. Wieser (Ed.), Fundamental researches in the western part of the Polish Carpathians. Guide to excursion 1. XIII CBGA Congress, Cracow, Poland, pp. 57-68.

Żelaźniewicz, A., Buła, Z., Fanning, M., Seghedi, A. and Żaba, J. 2009. More evidence on Neoproterozoic terranes in southern Poland and southeastern Romania. Geological Quarterly, 53, 93-124. 